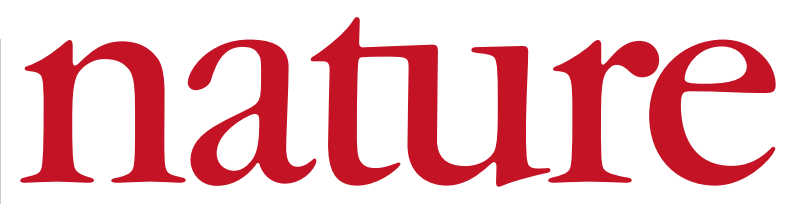

22 April 2004 Volume 428 Issue no 6985

\title{
Treading water
}

Some oceanographers were hoping that a commission chaired by James Watkins would propose more radical reform of ocean research, education and exploration.

$\mathrm{T}$ his week's report from the US Commission on Ocean Policy (see page 787) should lend valuable impetus to proposed legislation that would strengthen the mechanisms and financial support for ocean research.

As James Watkins, the commission's chair, has repeatedly pointed out, its work represents a rare opportunity to bring important issues, such as the declining health of marine ecosystems and bad fisheries management, to the fore. The exploration and management of the oceans is a widely neglected government function, not just in the United States, and the first review of ocean policy in 35 years provides a rare opportunity to overhaul it.

But critics of the present set-up are already arguing that the commission may have missed its chance. They say that its central proposal - to create a National Ocean Council at the White House - is insufficient to reconcile the conflicting policies that dog ocean management.

The commission could instead have recommended taking the National Marine Fisheries Service (NMFS), which regulates fish and other marine life, along with its parent agency, the National Oceanic and Atmospheric Administration (NOAA), out of the US Department of Commerce. Scientists at the NMFS and the rest of NOAA often say that they are constantly looking over their shoulders at pressures from commercial interests, which should not be allowed to override the wider public interest in sustainable ocean management.

Critics say that the NMFS would work better inside the Depart- ment of the Interior, or that NOAA could become an independent agency, like the space agency NASA, to whose budget and national profile oceanographers have often cast an envious eye. An alternative would be to create a cabinet-level Department of Natural Resources, combining agencies such as the NMFS with the interior department's resource services, as President Jimmy Carter proposed 25 years ago. This kind of radical surgery was endorsed last year by the nongovernmental Pew Oceans Commission (see Nature 423, 577; 2003). But Watkins' panel apparently felt that proposing a new agency in the current climate in Washington would be an exercise in futility.

Instead it urges government to "strengthen NOAA and improve the federal agency structure", and urges the doubling of the agency's research budget. It also suggests the creation of a trust fund, whereby the oil and gas industry, and other commercial users of offshore territory, would pay levies to help with ocean management.

Fortunately, the oceans have plenty of friends on both sides of the aisle in Congress - as does Admiral Watkins. Perhaps it is a shame that the commission didn't strike a bolder course. Even so, the report, along with the Pew commission's work and last year's National Academy of Sciences study on ocean exploration, puts Congress in a good position to legislate for the future health of the oceans. It should pass laws this year to strengthen NOAA and create a National Ocean Council at the White House, and ensure adequate support for a proposed integrated ocean-observing system.

\section{Organic farming enters the mainstream}

Conventional agriculture needs to plough furrows of knowledge that were dismissed until recently as marginal and esoteric.

T en years ago, few supermarkets stocked organic food, and those that did carried little more than some wilted lettuce and a basket of spotty apples - nothing to suggest that organic agriculture had a sparkling future. But now the future is here, and whole aisles of organic products in many stores command higher prices than food grown by conventional, intensive methods.

Researchers into organic methods have enjoyed a corresponding upsurge of interest in their work. Once relegated to the fringes of agricultural colleges and research stations, people who study composting and soil-organism biodiversity, for example, are now being taken seriously (see pages 792-798). Even the most intensive farmers are conscious of the need for farming methods that will be sustainable in the long term, and the research emphasis has shifted from maximizing yield to finding sustainable techniques. It is a moment to be savoured by proponents of organic agriculture and soil conservation, and presents an opportunity that must not be squandered.

Public discussions of organic farming, particularly in the news media, tend to be sharply polarized. Advocates insist that conventional farming exhausts the land and is unsustainable. Critics question the wisdom of farming with manure, and suggest that switching to less efficient methods is unethical when so many people in the world are hungry.

These debates tend to be heated in the scientific literature, too, with representatives of each point of view finding studies that back them up. Evidence can be produced to show that organic farms have higher yields or lower yields, produce more water-fouling nitrogen runoff or less. The resultant morass makes it tough for farmers and policy-makers to pin down the relevant facts.

This doesn't mean that the studies are necessarily flawed. It simply reflects the complexity of the systems being studied, and the number of variables involved. Straight comparisons of organic and conventional practice can often be misleading. Organic and conventional growers generally use different strains, for example, emphasizing pest resistance and yield, respectively. And organic farms change year to year, with yields improving and runoff decreasing over time as organic matter builds up and weed seeds disappear.

A better approach is to focus studies on particular issues of interest, such as soil conservation, nutrient retention and pest control. These should be done by collaborations between researchers who may have held differing views in the past. For too long, agricultural studies have tended to involve like-minded researchers and to be supported by a non-profit group, industrial company or government department that has an interest in the outcome. Now that such issues as soil conservation are acknowledged to be vital to all farmers, researchers with differing perspectives on the organic issue need to share their insights and seek out approaches that work. 